\title{
Perbandingan Cost Significant Model Dengan Metode Parametrik Untuk Estimasi Biaya Gedung Bertingkat 2 di Provinsi Sumatera Barat
}

\author{
Comparison of Cost Significant Models with Parametric Methods for \\ Estimating the Cost of 2-Storey Buildings \\ in Sumatra Province
}

\author{
Jajang Atmaja, Elvi Roza Syofyan \& Anne Fadillah
}

Jurusan Teknik Sipil Politeknik Negeri Padang Kampus Limau Manis Padang 25163

Telp. 0751-72590 Fax. 0751-72576 Email: jajang.atmaja@ymail.com, syofyan_er@yahoo.co.id \& anne18fadillah@gmail.com

\begin{abstract}
The estimated cost at the initial or conceptual stage is an estimate made when there is still little information about the image, description and specifications of the work to be done. This estimate is needed to provide information on the initial description of the total construction costs. Estimated costs must be accurate so as not to cause problems in the future. To obtain a method that meets these needs, we compare two estimation methods, namely the Cost Significant Model and the Metode Parametrik. This study aims to determine the components of the calculation needed by the Cost Significant Model and Parametric Method and the comparison of the two in making cost estimates and for determining the most accurate method. This research was applied to the construction of a 2-storey building in the province of West Sumatra. Data related to the study were collected from consultants in the city of Padang with 9 (nine) RAB data complete with project information originating from 2013 s.d. 2016

Based on the Cost Significant Model analysis, the regression analysis formula is obtained: $Y=1,340,187,179+$ 3,175 X2 + 0,295 X10 + 7,072 X11 + 1,881 X4 - 4,134 X13, where X2 is Foundation Work Cost, X10 is Wall Work Cost, X11 is Door Work Cost and Window, X4 is Column Work Costs, X13 is Floor Work Costs. This cost estimation model has been validated with an average error percentage of $0 \%$. Metode Parametrik Analysis using the formula set out in Presidential Regulation No. 73 of 2011 Article 14: Total Project Costs $=H S B G N x K x$ Project Area, where HSBGN is the Price of the State Building Building Unit and $K$ is the multiplier multiplier for multi-storey buildings. This cost estimation model has been validated with an average error percentage of $32 \%$. Based on the results of this error percentage, it is concluded that the most accurate method is the Cost Significant Model.

To obtain a small earth (near zero) resistivity value is determined by the number of planted electrodes and soil type properties. Difficulty in obtaining this small resistivity value often errors in estimating soil properties or soil type resistance so that failure to obtain soil barriers often occurs.

To determine the desired amount of material can be measured soil type resistor value, by measuring the soil resistivity value so that the estimated material cost estimation can be achieved well. then in this research using geoelectric method with Schlumberger configuration. Schlumberger method is a method with a constant system of spacing rules with the note of the ' $n$ ' multiplier is the comparison of the distance between the C1-P1 or (C2P2) electrodes with P1-P2. The instrument used is a resistivity meter ( Naniura) equipped with four electrodes which have the ability to read output voltage response due to current injected into the ground surface through two current electrodes and two potential electrodes. In this study used progress to map the $2 D$ isoresistivity beneath the measured surface. .

The results of this soil resistivity measurement can be determined with certainty the amount of material used and the cost of workmanship provided to establish the proper grounding system to be attached to a $20 \mathrm{kV}$ Distribution substation at the State Polytechnic Padang State Electricity Laboratory. So that the grounding system in pairs meet the standards that have been determined and can be categorized both and safe for humans and equipment for grounding Distribution Distributors $20 \mathrm{kV}$ Electricity Engineering Laboratory at the State Polytechnic Campus Padang.
\end{abstract}

Keywords : Cost Significant Model, Metode Parametrik, Analisis Regresi, RAB, KHSBGN 


\section{PENDAHULUAN}

Seorang owner memerlukan estimasi biaya untuk menentukan kebijakan dalam berinvestasi dan sebagai pertimbangan menentukan anggaran untuk besarnya kuantitas konstruksi yang dapat dikerjakan. Dalam estimasi biaya, khususnya tahap awal atau konseptual, kebanyakan owner mengestimasi menggunakan data proyek terdahulu. Perbandingan Cost Significant Model dan Metode Parametrik yang biasa digunakan pada tahap konseptual, bertujuan untuk mengetahui komponen perhitungan apa saja yang dibutuhkan Cost Significant Model dan Metode Parametrik serta perbandingan keduanya dalam melakukan estimasi biaya dan untuk menentukan metode yang paling akurat. Kedua metode ini diuji dengan mengestimasi kembali gedung bertingkat 2 (dua).

Menurut National Estimating SocietyUSA, perkiraan biaya adalah seni memperkirakan (the art of approximating), yaitu kemungkinan jumlah biaya yang diperlukan untuk suatu kegiatan yang didasarkan pada informasi yang tersedia pada waktu itu. Adapun tahapan estimasi biaya menurut Husen (2009), adalah sebagai berikut:

1. Tahap pengembangan konseptual, biaya total proyek dihitung secara umum dengan in-formasi yang minim.

2. Tahap desain konstruksi, biaya total proyek dihitung berdasarkan volume pekerjaan dan informasi harga satuan.

3. Tahap pelelangan, biaya total proyek dihitung oleh beberapa kontraktor untuk men-dapatkan penawaran terbaik, berdasarkan spesifikasi teknis dan gambar kerja, dalam usaha mendapatkan kontrak pekerjaan.

4. Tahap pelaksanaan, biaya total proyek dihitung lebih detail berdasarkan kuantitas pe-kerjaan, shop drawing dan metode pelaksanaan dengan ketelitian yang lebih tinggi.

Tingkat akurasi tahapan estimasi biaya dan metodenya menurut AACE
International (2005) ditunjukkan pada Tabel 1.

Tabel 1 Tingkat Akurasi Estimasi

\begin{tabular}{|c|c|c|c|}
\hline $\begin{array}{l}\text { Estimation } \\
\text { Class }\end{array}$ & $\begin{array}{c}\text { End Usage } \\
\text { (Typical purpose of escimate) }\end{array}$ & $\begin{array}{c}\text { Nethodology } \\
\text { (Typical estimating method) }\end{array}$ & $\begin{array}{l}\text { Expected Accuracy Range } \\
\text { (Typical lor and high range) }\end{array}$ \\
\hline Class 5 & Concept Screening & $\begin{array}{l}\text { Capacìy Factored, Parametic } \\
\text { Illodels, Judgment, or Analogy }\end{array}$ & $\begin{array}{l}\text { Lowr }-20 \% \text { to }-50 \% \\
\text { High }+30 \% \text { to }+100 \%\end{array}$ \\
\hline Class 4 & Study or Feasibity & $\begin{array}{l}\text { Equipment Factored or Parametic } \\
\text { Hodels }\end{array}$ & $\begin{array}{l}\text { Lowr }-15 \% \text { to }-30 \% \\
\text { High }+20 \% \text { to }+50 \%\end{array}$ \\
\hline Class 3 & Budget, Authorization, or Control & $\begin{array}{l}\text { Seni-Detaled Unit Cost with } \\
\text { Assemby Level Line lems }\end{array}$ & $\begin{array}{l}\text { Low. }-10 \% \text { to }-20 \% \\
\text { High }+10 \% \text { to }+30 \%\end{array}$ \\
\hline Class 2 & Control or BidTender & $\begin{array}{c}\text { Detaled Unit Cost with Forced } \\
\text { Detailed Take-Of }\end{array}$ & $\begin{array}{l}\text { Low }-5 \% \text { to }-15 \% \\
\text { high }+5 \% \text { to to }+20 \%\end{array}$ \\
\hline Class 1 & Check Estimate or BidTender & $\begin{array}{c}\text { Detailed Unit Cost with Detalied } \\
\text { Take-Off }\end{array}$ & $\begin{array}{l}\text { Lorr }-3 \% \text { to }-10 \% \\
\text { High }+3 \% \text { to }+15 \%\end{array}$ \\
\hline
\end{tabular}

Sumber: Christensen dan Dysert (2005)

Estimasi biaya tahap konseptual adalah perkiraan biaya konstruksi yang dilakukan sebelum sejumlah informasi yang signifikan terkumpul. Aktivitas utama dalam tahap ini ialah mengembangkan estimasi untuk menentukan kelayakan, menganalisa biaya alternatif, serta pemilihan desain yang optimal. Metode estimasi biaya pada tahap konseptual harus akurat dan mudah, untuk itu dibandingkan dua metode yang sesuai dengan hal ini yaitu Cost Significant Model dan Metode Parametrik.

Menurut Poh dan Horner (1995), Cost Significant adalah model peramalan biaya konstruksi berdasarkan informasi dan data proyek terdahulu, lebih mengandalkan harga paling signifikan yang mempengaruhi biaya total proyek, kemudian diterjemahkan kedalam analisis regresi. Metode ini menggunakan data dari proyek-proyek konstruksi terdahulu dan sejenis untuk merumuskan suatu model matematika sehingga dapat digunakan dalam proses estimasi. Penelitian ini mengolah data Bill of Quantity dari proyek-proyek terdahulu.

Estimasi biaya tahap awal yang sistematis, biasa dikenal sebagai estimasi biaya elemental atau parametrik, merupakan metode yang menelusuri biaya total proyek melalui parameter signifikan yang mempengaruhi biaya total proyek. 
Metode ini sering diterapkan pada konstruksi gedung, karena memiliki karakteristik yang relatif sama sehingga memudahkan dalam pengambilan parameter signifikan untuk perhitungan Metode Parametrik. Metode ini memiliki rumusan dan standar analisa yang telah ditetapkan oleh pemerintah.

\section{METODOLOGI}

\section{Studi Literatur}

Melalui tinjauan kepustakaan mengenai metode estimasi biaya proyek konstruksi yang berfokus pada proyek gedung bertingkat 2 (dua) dan mempelajari Cost Significant Model dan Metode Parametrik melalui buku referensi, jurnal ilmiah dan sumber lainnya.

\section{Pengumpulan Data}

Pengumpulan data dengan teknik Literature Review, berupa arsip kontrak penawaran pekerjaan yang telah dilaksanakan dalam kurun waktu tertentu, dengan acuan:

1. Data dari beberapa proyek yang sejenis dengan tahun yang berbeda

2. Data berupa Rencana Anggaran Biaya (RAB) lengkap dengan informasi proyek, dengan biaya tidak termasuk Pajak Pertambahan Nilai.

3. Data inflasi tahunan sesuai dengan tahun pelaksanaan data proyek yang ditinjau.

4. Data Harga Satuan Bangunan Gedung Negara (HSBGN) per $\mathrm{m}^{2}$ sesuai dengan klasifikasi bangunan dan tahun pelaksanaan proyek.

5. Koefesien/faktor pengali berdasarkan jenis bangunan yang diteliti

\section{Pengolahan Data}

Pengolahan data dilakukan dengan Cost Significant Model dan Metode Parametrik.

\section{Pengolahan Data dengan Cost Significant Model}

Pengolahan data dengan metode cost significant model melalui tahapan:

1. Identifikasi Variabel
Menentukan satu variabel terikat dan banyak variabel bebas.

2. Perhitungan Pengaruh Time Value

Perhitungan dilakukan untuk menyamakan nilai uang karena data berasal dari tahun yang berbeda-beda. Perhitungan dilakukan dengan rumus:

$\mathrm{FV} \quad=\mathrm{P}_{0}(1+\mathrm{i})^{\mathrm{n}}$

Keterangan:

FV : (Future Value), nilai dimasa mendatang (harga setelah diproyeksi)

$\mathrm{P}_{0} \quad$ : Nilai saat ini (harga pada sebelum diproyeksi)

i : : Tingkat suku bunga (faktor inflasi)

n : Jangka waktu (dari tahun asal s.d. tahun proyeksi)

3. Persentase Komponen Biaya

Menghitung persentase rata-rata tiap komponen biaya terhadap rata-rata total biaya total proyek.

4. Menentukan Cost Significant Items

Persentase variabel $\mathrm{X}$ yang diperoleh diurut dari yang terbesar ke terkecil. Cost Significant Items adalah item-item dengan kumulatif persentase $\leq 80 \%$.

5. Uji Normalitas Data

Dilakukan dengan program SPSS (Statistical Product and Service Solution) dan analisa Kolmogorov Smirnov. Data disebut normal jika nilai sig $>0,05$.

6. Uji Korelasi (R)

Dilakukan dengan program SPSS, untuk menganalisa kekuatan hubungan antara variabel terikat dan bebas. Nilai $R$ mendekati 1 , artinya hubungan $\mathrm{X}$ dengan Y sangat kuat, dan sebaliknya.

7. Nilai Koefesien Determinasi $\left(\mathrm{R}^{2}\right)$

Hasil analisanya diperoleh dalam uji korelasi dengan SPSS lalu dikalikan $100 \%$ atau manual dengan mengkuadratkan nilai $\mathrm{R}$ lalu dikalikan $100 \%$.

8. Analisa Data

Menggunakan Analisis Regresi Linear Berganda rumus sebagai berikut:

$\mathrm{Y}=\mathrm{a} 0+\mathrm{a} 1 \mathrm{X} 1+\mathrm{a} 2 \mathrm{X} 2 \ldots+\mathrm{an} \mathrm{Xn}$

Keterangan:

$\mathrm{Y}=$ Variabel terikat 


$\begin{array}{ll}\text { X1 s/d Xn } & =\text { Variabel bebas } \\ \text { a0 s/d an } & =\text { Koefisien } \\ & \text { persamaan }\end{array}$

Persamaan ini dapat langsung diperoleh dengan analisa regresi pada program SPSS. Persamaan ini digunakan untuk menghitung Biaya Estmasi Model.

9. Menentukan Cost Model Factor (CMF)

Cost Model Factor $(\mathrm{CMF})=$ Biaya

Estimasi Model Biaya Estimasi Aktual

10. Biaya Estimasi Cost Significant Model (CSM)

Biaya Estimasi CSM = Biaya Estimasi Model Rata-Rata CMF

11. Pengujian Akurasi Biaya Estimasi Cost Significant Model

$$
\text { Akurasi }=\frac{(E v-A v)}{A v} \times 100 \%
$$

Keterangan :

Ev : Biaya Estimasi Cost Significant Model

Av : Biaya Estimasi Aktual

\section{Pengolahan Data dengan Metode Parametrik}

Pengolahan data dengan metode parametrik melalui tahapan :

1. Menetapkan Parameter Atau Variabel Parameter yang digunakan adalah data luas keseluruhan bangunan.

2. Mengklasifikasikan bangunan yang diteliti sesuai dengan Peraturan Menteri Pekerjaan Umum No. 45/PRT/M/2007.

\section{HASIL}

Berikut adalah langkah-langkah analisa yang dilakukan:

\section{Identifikasi Variabel}

Variabel perhitungan yang akan digunakan adalah sebagai berikut:

a. Biaya Total Proyek, disebut variabel terikat dengan simbol (Y)

b. Komponen pekerjaan, disebut variabel bebas dengan simbol (X), terdiri dari:
1) Pekerjaan Persiapan (X1)
2) Pekerjaan Pondasi (X2)
3) Pekerjaan Sloof (X3)

4) Pekerjaan Kolom (X4)

5) Pekerjaan Balok (X5)

6) Pekerjaan Plat Lantai (X6)

7) Pekerjaan Atap (X7)

8) Pekerjaan Mekanikal Elektrikal (X8)

9) Pekerjaan Plumbing (X9)

10) Pekerjaan Dinding (X10)

11) Pekerjaan Pintu dan Jendela (X11)

12) Pekerjaan Plafond (X12)

13) Pekerjaan Lantai (X13)

14) Pekerjaan Finishing (X14)

Rekapitulasi data dapat dilihat pada Tabel 4 dan Tabel 5 .

Selanjutnya diperlukan penyederhanaan data, semua variabel dikonversikan dalam satuan $\mathrm{Rp} / \mathrm{m}^{2}$, dengan cara Biaya Total Proyek (Y) dan Biaya Komponen Pekerjaan (X1 s.d. X14) dibagi luas keseluruhan proyek masing-masing, rekapitulasi data dapat dilihat pada Tabel 6 dan Tabel 7 (halaman 11).

1. Perhitungan Pengaruh Time Value Untuk melakukan proyeksi harga dari tahun 2013 s.d. 2016 keharga pada tahun 2017, dibutuhkan data inflasi tahunan. Data inflasi yang digunakan berasal dari Badan Pusat Statistik (BPS) Provinsi Sumatera Barat, seperti pada Tabel 8.

Tabel 6 Inflasi Tahunan Provinsi Sumatera Barat

\begin{tabular}{|c|c|c|c|}
\hline No & Tahun & Inflasi (\%) & Inflasi \\
\hline 1 & 2013 & 10,87 & 0,1087 \\
\hline 2 & 2014 & 11,58 & 0,1158 \\
\hline 3 & 2015 & 1,08 & 0,0108 \\
\hline 4 & 2016 & 4,89 & 0,0489 \\
\hline
\end{tabular}

Sumber: BPS Sumatera Barat 


\section{PEMBAHASAN}

\section{Analisis Data dengan Metoda Kombinasi Grid dan Rod}

Tabel 4 Rekapitulasi Data Proyek Pembangunan Gedung 2 (dua) Lantai di Sumatera Barat Tahun 2013 s.d. 2016

\begin{tabular}{|c|c|c|c|c|c|c|c|c|c|c|}
\hline \multirow[b]{2}{*}{$\mathrm{N} 0}$. & \multirow[b]{2}{*}{ Tahun } & \multirow{2}{*}{$\begin{array}{c}\text { Biaya Total Provek (Y) } \\
(\mathrm{Rp})\end{array}$} & \multirow{2}{*}{$\begin{array}{c}\text { Luas } \\
\text { Provek }\left(\mathrm{m}^{2}\right)\end{array}$} & \multicolumn{7}{|c|}{ Komponen Biaya (Rp) } \\
\hline & & & & Pek. Persiapan (X1) & Pek.Pondasi (X2) & Pek. Sloof (X3) & Pek. Kolom (X4) & Pek. Balok (X5) & Pek. Plat Lantai (X6) & Pek. Atap (X7) \\
\hline 1 & 2013 & $2.086 .093 .446,30$ & 388,58 & $45.556 .582,00$ & $331.941 .425,07$ & $26.786 .200,00$ & $87.864 .800,00$ & $75.675 .600,00$ & $96.644 .400,00$ & $121.758 .412,01$ \\
\hline 2 & 2013 & $7.266 .000,375,55$ & 960,00 & $67.090 .285,60$ & $1.149,596,601,57$ & $434.133,398,12$ & $\mathbf{5 5 4} .611 .934,44$ & $1.016 .601 .985,76$ & $1.476 .637 .730,38$ & $98.978 .621,34$ \\
\hline 3 & 2014 & $4.548 .204 .154,40$ & 405,00 & 73.618.231,78 & $537,294,465,92$ & $112,844,275,85$ & $310.134 .706,89$ & $372.571 .538,11$ & $338.203 .738,25$ & $418.115 .376,87$ \\
\hline 4 & 2014 & $4.671 .727 .952,46$ & 405,00 & 73.618.231,78 & $642.344 .339,92$ & $112.844 .275,85$ & $310.134,706,89$ & $372.571 .538,11$ & $338.203 .738,25$ & $418.115 .376,87$ \\
\hline 5 & 2014 & $5.700 .000 .515,07$ & 1014,6 & $26.137 .100,00$ & $353.233 .674,39$ & $350.641 .877,05$ & $424.697 .527,54$ & $794.708 .029,97$ & $1.115 .857 .450,83$ & $272.414 .450,00$ \\
\hline 6 & 2014 & $3.697 .374 .603,80$ & 1084,85 & $27.464 .112,00$ & $362.503 .167,00$ & $130,375.863,31$ & $443.531 .788,44$ & $392.434,444,37$ & $691.828 .102,81$ & $112.205 .942,25$ \\
\hline 7 & 2015 & $1.866 .943 .065,59$ & 493,22 & $60,392.168,64$ & $272,899.123,89$ & $45.775 .265,01$ & $64.346 .707,06$ & $110.182 .195,02$ & $100.905 .676,14$ & $222,291,448,88$ \\
\hline 8 & 2015 & $5.454 .548 .961,67$ & 1500,00 & $39,056,922,12$ & $237,652.341,61$ & $215.208 .942,20$ & $412,956.238,48$ & $531,348,590,96$ & $735.040 .882,29$ & $332.428 .148,89$ \\
\hline 9 & 2016 & 2.195.454.811,12 & 515,53 & $7.000 .000,00$ & 68.583.201,38 & $92,379.624,36$ & $194.637 .256,92$ & $317.718 .415,56$ & $157.707 .717,39$ & $190.140 .990,48$ \\
\hline
\end{tabular}

Sumber: Pengolahan Data Ms. Excel

Tabel 5 Lanjutan Rekapitulasi Data Proyek Pembangunan Gedung 2 (dua) Lantai di Sumatera Barat Tahun 2013 s.d. 2016

\begin{tabular}{|c|c|c|c|c|c|c|c|c|c|c|}
\hline \multirow[b]{2}{*}{ No. } & \multirow[b]{2}{*}{ Tahun } & \multirow{2}{*}{$\begin{array}{c}\text { Biaya Tiotal Proyek (Y) } \\
\text { (Rp) }\end{array}$} & \multirow{2}{*}{$\begin{array}{c}\text { Luas } \\
\text { Proyek }\left(\mathrm{m}^{2}\right)\end{array}$} & \multicolumn{7}{|c|}{ Komponen Biaya (Rp) } \\
\hline & & & & Pek. MEE(X8) & Pek. Plumbing (X9) & Pek. Dinding $(\mathrm{X} 10)$ & $\begin{array}{l}\text { Pek. Pintu \& Jendela } \\
\text { (X11) }\end{array}$ & Pek.Plafond (X12) & Pek. Lantai (X13) & Pek. Finishing (X14) \\
\hline 1 & 2013 & $2.086 .093,446,30$ & 388,58 & $225.625 .400,00$ & $231.118,415,37$ & $402.516,325,47$ & $131.192 .800,00$ & 98.656.858,07 & $145.452,052,62$ & $65.304,175,69$ \\
\hline 2 & 2013 & $7,266.000,375,55$ & 960,00 & $225.239,500,00$ & $170.416 .701,66$ & $604.261 .479,74$ & $529.847 .974,90$ & $251,811,364,67$ & $574,322,273,88$ & $112,450,523,49$ \\
\hline 3 & 2014 & $4,548.204 .154,40$ & 405,00 & $325.842,300,50$ & $81.704 .608,47$ & $626.446,912,94$ & $401.921 .569,86$ & $157.513,941,26$ & $298.103 .856,62$ & $331.665 .295,77$ \\
\hline 4 & 2014 & $4.671 .727 .952,46$ & 405,00 & $325.842,300,50$ & $81.704 .608,47$ & $626.446 .912,94$ & $401.921 .569,86$ & $157.513,941,26$ & $298.103 .856,62$ & $331.665 .295,77$ \\
\hline 3 & 2014 & $5.700 .000 .515,07$ & 1014,6 & $404.725 .200,00$ & $349.568 .687,11$ & $423.999,347,55$ & $462.876,805,17$ & $354,319,646,10$ & $200,306.403,37$ & $166.514,316,00$ \\
\hline 6 & 2014 & $3.697,374,603,80$ & 1084,85 & $148.030,000,00$ & $98.409,429,00$ & $406.217,535,39$ & $288.096,008,58$ & $269.275 .710,15$ & $280,209,955,25$ & $46.792,545,25$ \\
\hline 7 & 2015 & $1.866 .943 .065,59$ & 493,22 & $147.840,000,00$ & $58.554 .825,19$ & $256.500 .738,30$ & $153.867 ., 29,56$ & $78.367 .909,46$ & $181,291.486,32$ & $75.860 .755,50$ \\
\hline 8 & 2015 & $5.454 .548 .961,67$ & 1500,00 & $326.485 .415,00$ & $163.597,553,35$ & $571.189,720,40$ & $515.081,346,02$ & $228.537,438,55$ & $547,400,332,49$ & $514,168.815,54$ \\
\hline 9 & 2016 & $2.195 .454 .811,12$ & 515,53 & $37,250,000,00$ & $126.000,413,46$ & $293.410,959,91$ & $276,375,365,41$ & $108.590 .919,61$ & $253.472,381,23$ & $72.187 .565,41$ \\
\hline
\end{tabular}
Sumber: Pengolahan Data Ms. Excel

Tabel 6 Variabel Data Proyek disederhanakan dalam Satuan Rp/m²

\begin{tabular}{|c|c|c|c|c|c|c|c|c|c|}
\hline \multirow[b]{2}{*}{ No. } & \multirow[b]{2}{*}{ Tahun } & \multirow{2}{*}{$\begin{array}{l}\text { Biaya Total Proyek } \\
\text { (Y) }\left(\mathrm{Rp} / \mathrm{m}^{2}\right)\end{array}$} & \multicolumn{7}{|c|}{ Komponen Biaya $\left(\mathrm{Rp} / \mathrm{m}^{2}\right)$} \\
\hline & & & $\begin{array}{l}\text { Pek. Persiapan } \\
\text { (X1) }\end{array}$ & Pek. Pondasi (X2) & Pek. Sloof (X3) & Pek. Kolom (X4) & Pek. Balok (X5) & $\begin{array}{l}\text { Pek. Plat Lantai } \\
\text { (X6) }\end{array}$ & Pek. Atap (X7) \\
\hline 1 & 2013 & $5.368 .504,42$ & $117.238,62$ & $854.242,18$ & $68.933,55$ & $226.117,66$ & $194.749,09$ & $248.711,72$ & $313.341,94$ \\
\hline 2 & 2013 & $7.568 .750,39$ & $69.885,71$ & $1.197 .496,46$ & $452.222,29$ & $577.720,77$ & $1.058 .960,40$ & $1.538 .164,30$ & $103.102,73$ \\
\hline 3 & 2014 & $11.230 .133,71$ & $181.773,41$ & $1.326 .653,00$ & $278.627,84$ & $765.764,71$ & $919.929,72$ & $835.070,96$ & $1.032 .383,65$ \\
\hline 4 & 2014 & $11.535 .130,75$ & $181.773,41$ & $1.586 .035,41$ & $278.627,84$ & $765.764,71$ & $919.929,72$ & $835.070,96$ & $1.032 .383,65$ \\
\hline 5 & 2014 & $5.617 .978,04$ & $25.760,99$ & $348.150,67$ & $345.596,17$ & $418.586,17$ & $783.272,26$ & $1.099 .800,37$ & $268.494,43$ \\
\hline 6 & 2014 & $3.408 .189,71$ & $25.316,05$ & $334.150,50$ & $120.178,70$ & $408.841,58$ & $361.740,74$ & $637.717,75$ & $103.429,91$ \\
\hline 7 & 2015 & $3.785 .213,63$ & $122.444,69$ & $553.301,01$ & $92.809,02$ & $130.462,49$ & $223.393,61$ & $204.585,53$ & $450.694,31$ \\
\hline 8 & 2015 & $3.636 .365,97$ & $26.037,95$ & $158.434,89$ & $143.472,63$ & $275.304,16$ & $354.232,39$ & $490.027,25$ & $221.618,77$ \\
\hline 9 & 2016 & $4.258 .636,38$ & $13.578,26$ & $133.034,36$ & $179.193,50$ & $377.547,88$ & $616.294,72$ & $305.913,75$ & $368.826,24$ \\
\hline
\end{tabular}

Sumber: Pengolahan Data Ms. Excel 
Tabel 7 Lanjutan Variabel Data Proyek disederhanakan dalam Satuan Rp/m²

\begin{tabular}{|c|c|c|c|c|c|c|c|c|c|}
\hline \multirow[b]{2}{*}{ No. } & \multirow[b]{2}{*}{ Tahun } & \multirow{2}{*}{$\begin{array}{l}\text { Biaya Total Proyek } \\
\text { (Y) }\left(\mathrm{Rp} / \mathrm{m}^{2}\right)\end{array}$} & \multicolumn{7}{|c|}{ Komponen Biaya (Rp/m²) } \\
\hline & & & Pek. M.E(X8) & $\begin{array}{l}\text { Pek. Plumbing } \\
\text { (X9) }\end{array}$ & $\begin{array}{l}\text { Pek. Dinding } \\
\text { (X10) }\end{array}$ & $\begin{array}{l}\text { Pek.Pintu \& } \\
\text { Jendela (X11) }\end{array}$ & $\begin{array}{l}\text { Pek. Plafond } \\
\text { (X12) }\end{array}$ & $\begin{array}{c}\text { Pek. Lantai } \\
\text { (X13) }\end{array}$ & $\begin{array}{l}\text { Pek. Finishing } \\
\text { (X14) }\end{array}$ \\
\hline 1 & 2013 & $5.368 .504,42$ & $580.640,79$ & $594.776,92$ & $1.035 .864,75$ & $337.621,08$ & $253.890,73$ & $374.316,88$ & $168.058,51$ \\
\hline 2 & 2013 & 7.568.750,39 & $234.624,48$ & $177.517,40$ & $629.439,04$ & $551.924,97$ & $262.303,50$ & $598.252,37$ & $117.135,96$ \\
\hline 3 & 2014 & $11.230 .133,71$ & $804.548,89$ & $201.739,77$ & $1.546 .782,50$ & 992.398,94 & $388.923,31$ & $736.058,91$ & $818.926,66$ \\
\hline 4 & 2014 & $11.535 .130,75$ & $804.548,89$ & $201.739,77$ & $1.546 .782,50$ & $992.398,94$ & $388.923,31$ & $736.058,91$ & $818.926,66$ \\
\hline 5 & 2014 & $5.617 .978,04$ & $398.901,24$ & $344.538,43$ & $417.898,04$ & $456.216,05$ & $349.221,02$ & $197.424,01$ & $164.118,19$ \\
\hline 6 & 2014 & 3.408.189,71 & $136.452,04$ & $90.712,48$ & $374.445,81$ & $265.562,99$ & $248.214,69$ & $258.293,73$ & $43.132,73$ \\
\hline 7 & 2015 & $3.785 .213,63$ & $299.744,54$ & $118.719,49$ & $520.053,40$ & $311.965,71$ & $158.890,37$ & $367.567,18$ & $153.807,14$ \\
\hline 8 & 2015 & 3.636.365,97 & $217.656,94$ & $109.065,04$ & $380.793,15$ & $343.387,56$ & $152.358,29$ & $364,933,55$ & $342.779,21$ \\
\hline 9 & 2016 & $4.258 .636,38$ & $72.255,74$ & 244.409,47 & $569.144,30$ & $536.099,48$ & $210.639,38$ & $491.673,39$ & $140.025,93$ \\
\hline
\end{tabular}

Sumber: Pengolahan Data Ms. Excel

Tabel 9 Variabel Data Proyek diproyeksikan pada Tahun 2017

\begin{tabular}{|c|c|c|c|c|c|c|c|c|}
\hline \multirow[b]{2}{*}{ No. } & \multirow{2}{*}{$\begin{array}{l}\text { Biaya Total Proyek } \\
\text { (Y) }\left(\mathrm{Rp} / \mathrm{m}^{2}\right)\end{array}$} & \multicolumn{7}{|c|}{ Komponen Biaya $\left(\mathrm{Rp} / \mathrm{m}^{2}\right)$} \\
\hline & & $\begin{array}{l}\text { Pek. Persiapan } \\
\text { (X1) }\end{array}$ & Pek. Pondasi (X2) & Pek. Sloof (X3) & Pek. Kolom (X4) & Pek. Balok (X5) & $\begin{array}{l}\text { Pek. Plat Lantai } \\
\text { (X6) }\end{array}$ & Pek. Atap (X7) \\
\hline 1 & $8.111 .655,63$ & $177.144,18$ & $1.290 .735,34$ & $104.156,61$ & $341.657,27$ & $294.260,26$ & $375.796,25$ & $473.450,65$ \\
\hline 2 & $11.436 .163,96$ & $105.595,30$ & $1.809 .382,68$ & $683.294,86$ & $872.919,44$ & $1.600 .058,68$ & 2.324.121,98 & $155.785,26$ \\
\hline 3 & $15.600 .696,88$ & $252.516,31$ & $1.842 .962,15$ & $387.064,71$ & $1.063 .786,36$ & $1.277 .949,59$ & $1.160 .065,34$ & $1.434 .168,53$ \\
\hline 4 & $16.024 .393,19$ & $252.516,31$ & $2.203 .291,45$ & $387.064,71$ & $1.063 .786,36$ & $1.277 .949,59$ & $1.160 .065,34$ & $1.434 .168,53$ \\
\hline 5 & 7.804.392,59 & $35.786,70$ & $483.644,57$ & $480.095,90$ & $581.492,27$ & 1.088.107,53 & $1.527 .822,60$ & $372.987,57$ \\
\hline 6 & 4.734.594,96 & $35.168,59$ & $464.195,77$ & $166.950,06$ & $567.955,26$ & $502.523,64$ & $885.905,87$ & $143.682,95$ \\
\hline 7 & $3.867 .415,75$ & $125.103,77$ & $565.316,85$ & $94.824,52$ & $133.295,69$ & $228.244,97$ & $209.028,44$ & $460.481,88$ \\
\hline 8 & $3.715 .335,63$ & $26.603,40$ & $161.875,57$ & $146.588,37$ & $281.282,84$ & $361.925,13$ & $500.669,00$ & $226.431,58$ \\
\hline 9 & $4.466 .883,70$ & $14.242,24$ & $139.539,74$ & $187.956,06$ & $396.009,97$ & $646.431,53$ & $320.872,94$ & $386.861,84$ \\
\hline
\end{tabular}

Sumber: Pengolahan Data Ms. Excel

Tabel 10 Variabel Data Proyek diproyeksikan pada Tahun 2017

\begin{tabular}{|c|c|c|c|c|c|c|c|c|}
\hline \multirow[b]{2}{*}{ No. } & \multirow{2}{*}{$\begin{array}{l}\text { Biaya Total Proyek } \\
(\mathrm{Y})\left(\mathrm{Rp} / \mathrm{m}^{2}\right)\end{array}$} & \multicolumn{7}{|c|}{ Komponen Biaya $\left(\mathrm{Rp} / \mathrm{m}^{2}\right)$} \\
\hline & & Pek. M.E(X8) & $\begin{array}{l}\text { Pek. Plumbing } \\
\text { (X9) }\end{array}$ & $\begin{array}{l}\text { Pek. Dinding } \\
\text { (X10) }\end{array}$ & $\begin{array}{l}\text { Pek. Pintu \& } \\
\text { Jendela (X11) }\end{array}$ & $\begin{array}{l}\text { Pek. Plafond } \\
\text { (X12) }\end{array}$ & Pek. Lantai (X13) & $\begin{array}{l}\text { Pek. Finishing } \\
\text { (X14) }\end{array}$ \\
\hline 1 & $8.111 .655,63$ & $877.331,53$ & $898.690,80$ & $1.565 .161,82$ & $510.135,74$ & $383.621,58$ & $565.582,03$ & 253.931,57 \\
\hline 2 & $11.436 .163,96$ & $354.510,83$ & $268.223,68$ & $951.064,27$ & $833.942,75$ & $396.333,04$ & $903.942,11$ & $176.989,07$ \\
\hline 3 & $15.600 .696,88$ & $1.117 .664,64$ & $280.253,21$ & $2.148 .762,03$ & $1.378 .622,50$ & $540.285,17$ & $1.022 .519,60$ & 1.137.637,97 \\
\hline 4 & $16.024 .393,19$ & $1.117 .664,64$ & $280.253,21$ & $2.148 .762,03$ & $1.378 .622,50$ & $540.285,17$ & $1.022 .519,60$ & $1.137 .637,97$ \\
\hline 5 & $7.804 .392,59$ & $554.146,33$ & $478.626,50$ & $580.536,33$ & $633.767,01$ & $485.131,47$ & $274.257,84$ & $227.990,00$ \\
\hline 6 & $4.734 .594,96$ & $189.556,69$ & $126.016,12$ & $520.173,29$ & $368.915,26$ & $344.815,32$ & $358.816,94$ & $59.919,21$ \\
\hline 7 & $3.867 .415,75$ & $306.253,98$ & $121.297,67$ & $531.347,21$ & $318.740,56$ & $162.340,94$ & $375.549,51$ & $157.147,31$ \\
\hline 8 & $3.715 .335,63$ & $222.383,72$ & $111.433,56$ & $389.062,69$ & $350.844,79$ & $155.667,00$ & $372.858,69$ & $350.223,22$ \\
\hline 9 & $4.466 .883,70$ & $75.789,04$ & $256.361,09$ & $596.975,45$ & $562.314,75$ & $220.939,65$ & $515.716,22$ & $146.873,19$ \\
\hline
\end{tabular}

Sumber: Pengolahan Data Ms. Excel 


\section{Proporsi Komponen Biaya}

Hasil perhitungan dapat dilihat pada Tabel 11.

Tabel 11 Persentase Variabel X terhadap Variabel Y

\begin{tabular}{|c|c|c|c|c|c|c|}
\hline No & Uraian & Simbol & $\begin{array}{c}\text { Banyak } \\
\text { Paket } \\
\text { Pekerjaan }\end{array}$ & $\begin{array}{c}\text { Jumlah Per } \\
\text { Variabel } \\
\left(\mathbf{R p} / \mathbf{m}^{2}\right)\end{array}$ & $\begin{array}{c}\text { Rata-Rata Per } \\
\text { Variabel }\left(\mathbf{R p} / \mathbf{m}^{2}\right)\end{array}$ & $\begin{array}{c}\text { Persentase } \mathrm{X} \\
\text { terhadap Y }\end{array}$ \\
\hline & & & $\mathbf{a}$ & b & $c=b / a$ & \\
\hline 1 & Biaya Total Proyek & $\mathbf{Y}$ & 9 & 75.761.532,28 & $8.417 .948,03$ & $100 \%$ \\
\hline 2 & Pek. Persiapan & $\mathrm{X} 1$ & 9 & 1.024.676,79 & $113.852,98$ & $1 \%$ \\
\hline 3 & Pek. Pondasi & $\mathrm{X} 2$ & 9 & $8.960 .944,11$ & $995.660,46$ & $12 \%$ \\
\hline 4 & Pek. Sloof & $\mathrm{X3}$ & 9 & $2.637 .995,81$ & $293.110,65$ & $3 \%$ \\
\hline 5 & Pek. Kolom & $\mathrm{X} 4$ & 9 & 5.302.185,48 & $589.131,72$ & $7 \%$ \\
\hline 6 & Pek. Balok & $\mathrm{X5}$ & 9 & 7.277.450,92 & $808.605,66$ & $10 \%$ \\
\hline 7 & Pek. Plat Lantai & X6 & 9 & $8.464 .347,76$ & $940.483,08$ & $11 \%$ \\
\hline 8 & Pek. Atap & $\mathrm{X} 7$ & 9 & 5.088.018,78 & $565.335,42$ & $7 \%$ \\
\hline 9 & Pek. M.E & X8 & 9 & 4.815.301,40 & $535.033,49$ & $6 \%$ \\
\hline 10 & Pek. Plumbing & X9 & 9 & $2.821 .155,85$ & $313.461,76$ & $4 \%$ \\
\hline 11 & Pek. Dinding & X10 & 9 & 9.431.845,13 & $1.047 .982,79$ & $12 \%$ \\
\hline 12 & Pek. Pintu \& Jendela & X11 & 9 & $6.335 .905,85$ & 703.989,54 & $8 \%$ \\
\hline 13 & Pek. Plafond & X12 & 9 & 3.229.419,34 & $358.824,37$ & $4 \%$ \\
\hline 14 & Pek. Lantai & $\mathrm{X} 13$ & 9 & $5.411 .762,53$ & $601.306,95$ & $7 \%$ \\
\hline 15 & Pek. Finishing & X14 & 9 & 3.648.349,51 & 405.372,17 & $5 \%$ \\
\hline
\end{tabular}

Sumber: Pengolahan Data Ms. Excel

\section{Menentukan Cost Significant Items (CSI)}

Hasil penentuan Cost Significant Items dapat dilihat pada Tabel 12.

Tabel 12 Penentuan Cost Significant Items

\begin{tabular}{|c|c|c|c|c|c|}
\hline No & Uraian & Simbol & $\begin{array}{c}\text { Persentase X } \\
\text { terhadap Y }\end{array}$ & $\begin{array}{c}\text { Persentase } \\
\text { Kumulatif }\end{array}$ & Hasil Analisa \\
\hline 1 & Biaya Total Proyek & $\mathbf{Y}$ & $100 \%$ & & \\
\hline 2 & Pek. Pondasi & $\mathbf{X} 2$ & $12 \%$ & $12 \%$ & \multirow{9}{*}{ Cost Significant Item } \\
\hline 3 & Pek. Dinding & $\mathbf{X 1 0}$ & $12 \%$ & $24 \%$ & \\
\hline 4 & Pek. Plat Lantai & X6 & $11 \%$ & $35 \%$ & \\
\hline 5 & Pek. Balok & X5 & $10 \%$ & $45 \%$ & \\
\hline 6 & Pek. Pintu \& Jendela & $\mathbf{X 1 1}$ & $8 \%$ & $53 \%$ & \\
\hline 7 & Pek. Kolom & $\mathbf{X 4}$ & $7 \%$ & $60 \%$ & \\
\hline 8 & Pek. Atap & $\mathbf{X 7}$ & $7 \%$ & $67 \%$ & \\
\hline 9 & Pek. Lantai & $\mathbf{X 1 3}$ & $7 \%$ & $74 \%$ & \\
\hline 10 & Pek. M.E & $\mathbf{X 8}$ & $6 \%$ & $81 \%$ & \\
\hline 11 & Pek. Finishing & X14 & $5 \%$ & $85 \%$ & \\
\hline 12 & Pek. Plumbing & X9 & $4 \%$ & $89 \%$ & \\
\hline 13 & Pek. Plafond & $\mathbf{X 1 2}$ & $4 \%$ & $93 \%$ & \\
\hline 14 & Pek. Sloof & $\mathbf{X 3}$ & $3 \%$ & $97 \%$ & \\
\hline 15 & Pek. Persiapan & X1 & $1 \%$ & $98 \%$ & \\
\hline
\end{tabular}

Sumber: Pengolahan Data Ms. Excel

\section{Uji Normalitas Data}

Hasil uji normalitas data CSI dengan SPSS dapat dilihat pada Tabel 13. 
Tabel 13 Hasil Uji Normalitas Data

\begin{tabular}{|c|l|c|c|l|}
\hline No. & \multicolumn{1}{|c|}{ Uraian } & Simbol & $\begin{array}{c}\text { Probabilitas } \\
\text { (Sig.) }\end{array}$ & \multicolumn{1}{|c|}{ Hasil Analisa } \\
\hline 1 & Pek. Pondasi & X2 & 0,261 & $*$ nilai Sig $>0,05$, maka data berdistribusi normal \\
\hline 2 & Pek. Dinding & X10 & 0,291 & $*$ nilai Sig $>0,05$, maka data berdistribusi normal \\
\hline 3 & Pek. Plat Lantai & X6 & 0,183 & $*$ nilai Sig $>0,05$, maka data berdistribusi normal \\
\hline 4 & Pek. Balok & X5 & 0,181 & $*$ nilai Sig $>0,05$, maka data berdistribusi normal \\
\hline 5 & Pek. Pintu \& Jendela & X11 & 0,234 & $*$ nilai Sig $>0,05$, maka data berdistribusi normal \\
\hline 6 & Pek. Kolom & X4 & 0,176 & $*$ nilai Sig $>0,05$, maka data berdistribusi normal \\
\hline 7 & Pek. Atap & X7 & 0,350 & $*$ nilai Sig $>0,05$, maka data berdistribusi normal \\
\hline 8 & Pek. Lantai & X13 & 0,218 & $*$ nilai Sig $>0,05$, maka data berdistribusi normal \\
\hline 9 & Pek. M.E & X8 & 0,237 & $*$ nilai Sig $>0,05$, maka data berdistribusi normal \\
\hline
\end{tabular}

Sumber: Pengolahan Data SPSS dan Ms. Excel

\section{Uji Korelasi}

Hasil uji korelasi data CSI dapat dilihat pada Tabel 14.

Tabel 14 Hasil Analisa Uji Korelasi Pearson

\begin{tabular}{|c|c|c|c|c|c|}
\hline No & Uraian & Simbol & $\begin{array}{c}\text { Pearson } \\
\text { Correlation } \\
\text { (R) }\end{array}$ & $\begin{array}{c}\text { Probabilitas } \\
\text { (Sig) }\end{array}$ & Hasil Analisa \\
\hline 1 & Pek. Pondasi & $\mathrm{X} 2$ & 0,936 & 0,000 & \begin{tabular}{|l}
$*$ nilai $\mathrm{R} 0,81 \mathrm{~s} / \mathrm{d} 1,00=$ korelasi sempurna \\
$*$ nilai sig $<0,05$, maka berkorelasi
\end{tabular} \\
\hline \multirow[t]{2}{*}{2} & \multirow[t]{2}{*}{ Pek. Dinding } & \multirow[t]{2}{*}{$\mathrm{X} 10$} & \multirow[t]{2}{*}{0,903} & \multirow[t]{2}{*}{0,001} & $*$ nilai $\mathrm{R} 0,81 \mathrm{~s} / \mathrm{d} 1,00=$ korelasi sempurna \\
\hline & & & & & $*$ nilai sig $<0,05$, maka berkorelasi \\
\hline \multirow[t]{2}{*}{3} & \multirow{2}{*}{$\begin{array}{l}\text { Pek. Plat } \\
\text { Lantai }\end{array}$} & \multirow[t]{2}{*}{ X6 } & \multirow[t]{2}{*}{0,568} & \multirow[t]{2}{*}{0,111} & $*$ nilai $\mathrm{R} 0,41 \mathrm{~s} / \mathrm{d} 0,60=$ korelasi sedang \\
\hline & & & & & $*$ nilai sig $>0,05$, maka tidak berkorelasi \\
\hline \multirow[t]{2}{*}{4} & \multirow[t]{2}{*}{ Pek. Balok } & \multirow[t]{2}{*}{$\mathrm{X5}$} & \multirow[t]{2}{*}{0,797} & \multirow[t]{2}{*}{0,010} & $*$ nilai $\mathrm{R} 0,61 \mathrm{~s} / \mathrm{d} 0,80=$ korelasi kuat \\
\hline & & & & & $*$ nilai sig $<0,05$, maka berkorelasi \\
\hline \multirow[t]{2}{*}{5} & \multirow{2}{*}{$\begin{array}{l}\text { Pek. Pintu \& } \\
\text { Jendela }\end{array}$} & \multirow[t]{2}{*}{$\mathrm{X} 11$} & \multirow[t]{2}{*}{0,967} & \multirow[t]{2}{*}{0,000} & $*$ nilai $\mathrm{R} 0,81 \mathrm{~s} / \mathrm{d} 1,00=$ korelasi sempurna \\
\hline & & & & & $*$ nilai sig < 0,05, maka berkorelasi \\
\hline \multirow[t]{2}{*}{$\overline{6}$} & \multirow[t]{2}{*}{ Pek. Kolom } & \multirow[t]{2}{*}{$\mathrm{X} 4$} & \multirow[t]{2}{*}{0,923} & \multirow[t]{2}{*}{0,000} & $*$ nilai R $0,81 \mathrm{~s} / \mathrm{d} 1,00=$ korelasi sempurna \\
\hline & & & & & $*$ nilai sig $<0,05$, maka berkorelasi \\
\hline \multirow[t]{2}{*}{7} & \multirow[t]{2}{*}{ Pek. Atap } & \multirow[t]{2}{*}{$\mathrm{X7}$} & \multirow[t]{2}{*}{0,811} & \multirow[t]{2}{*}{0,008} & $*$ nilai R $0,81 \mathrm{~s} / \mathrm{d} 1,00=$ korelasi sempurna \\
\hline & & & & & $*$ nilai sig $<0,05$, maka berkorelasi \\
\hline \multirow[t]{2}{*}{8} & \multirow[t]{2}{*}{ Pek. Lantai } & \multirow[t]{2}{*}{$\mathrm{X} 13$} & \multirow[t]{2}{*}{0,909} & \multirow[t]{2}{*}{0,001} & $*$ nilai R $0,81 \mathrm{~s} / \mathrm{d} 1,00=$ korelasi sempurna \\
\hline & & & & & $*$ nilai sig $<0,05$, maka berkorelasi \\
\hline \multirow[t]{2}{*}{9} & \multirow[t]{2}{*}{ Pek. M.E } & $\mathrm{X} 8$ & 0,803 & 0,009 & $*$ nilai $\mathrm{R} 0,61 \mathrm{~s} / \mathrm{d} 0,80=$ korelasi kuat \\
\hline & & & & & $*$ nilai sig < 0,05, maka berkorelasi \\
\hline
\end{tabular}

Sumber: Pengolahan Data SPSS dan Ms. Excel

Dalam penelitian ini Variabel $X$ yang memenuhi syarat adalah yang memiliki nilai $R \geq 0,9$, yaitu Variabel: X2, X10, X11, X4 dan X13

\section{Menentukan Nilai Koefesien Determinasi $\left(\mathbf{R}^{2}\right)$}

Hasil uji determinasi merupakan hasil uji koefesien korelasi ulang pada Variabel X2,X10, X11, X4 dan X13 terhadap Variabel Y, dan menghasilkan Tabel Model Summary yang memuat nilai $\mathrm{R}^{2}$ ( $R$ Square), yang dapat dilihat pada Tabel 15.

Tabel 15 Hasil Analisa Uji Korelasi Pearson 


\begin{tabular}{|c|c|c|c|c|c|}
\hline \multicolumn{5}{|c|}{ Model Summary $^{\mathbf{b}}$} \\
\hline Model & $\mathrm{R}$ & R Square & $\begin{array}{c}\text { Adjusted R } \\
\text { Square }\end{array}$ & $\begin{array}{c}\text { Std. Error of the } \\
\text { Estimate }\end{array}$ & $\begin{array}{c}\text { Durbin- } \\
\text { Watson }\end{array}$ \\
\hline 1 & 0,998 & 0,995 & 0,987 & $563.112,36670$ & 2,377 \\
\hline
\end{tabular}

a. Predictors: (Constant), X13, X4, X10, X2, X11

b. Dependent Variable: Y

Sumber: Pengolahan Data SPSS

Hasil analisa koefesien determinasi adalah 0,995 atau sebesar 99,5\%.

\section{Pembuatan Cost Significant Model}

Uji ulang Koefesien Korelasi, juga menghasilkan output Tabel Coeffecient yang menjadi dasar Cost Significant ModeI, yang dapat dilihat pada Tabel 16.

Tabel 16 Hasil Analisa Uji Korelasi Pearson

\begin{tabular}{|c|c|c|c|c|c|}
\hline \multicolumn{2}{|c|}{ Model } & \multicolumn{2}{|c|}{ Unstandardized Coefficients } & \multirow{2}{*}{$\begin{array}{c}\begin{array}{c}\text { Standardized } \\
\text { Coefficients }\end{array} \\
\text { Beta } \\
\end{array}$} & \multirow[t]{2}{*}{ Sig. } \\
\hline & & B & Std. Error & & \\
\hline \multirow[t]{6}{*}{1} & (Constant) & 1340187,179 & 567036,195 & & 0,099 \\
\hline & $\mathrm{X} 2$ & 3,175 & 0,814 & 0,518 & 0,030 \\
\hline & $\mathrm{X} 10$ & 0,295 & 0,861 & 0,043 & 0,754 \\
\hline & $\mathrm{X} 11$ & 7,072 & 2,218 & 0,600 & 0,050 \\
\hline & $\mathrm{X} 4$ & 1,881 & 1,921 & 0,131 & 0,400 \\
\hline & $\mathrm{X} 13$ & $-4,124$ & 2,091 & $-0,254$ & 0,143 \\
\hline
\end{tabular}

Sumber: Pengolahan Data SPSS

Berdasarkan hasil uji diatas, maka diperoleh persamaan regresi sebagai berikut:

$\mathrm{Y}=1.340 .187,179+3,175 \mathrm{X} 2+0,295 \mathrm{X} 10+7,072 \mathrm{X} 11+1,881 \mathrm{X} 4-4,134 \mathrm{X} 13$

Keterangan:

$\mathrm{Y}=$ Biaya Total Proyek $\left(\mathrm{Rp} / \mathrm{m}^{2}\right)$

$\mathrm{X} 2 \quad=$ Biaya Pekerjaan Pondasi $\left(\mathrm{Rp} / \mathrm{m}^{2}\right)$

$\mathrm{X} 10=$ Biaya Pekerjaan Dinding $\left(\mathrm{Rp} / \mathrm{m}^{2}\right)$

$\mathrm{X} 11=$ Biaya Pekerjaan Pintu dan Jendela $\left(\mathrm{Rp} / \mathrm{m}^{2}\right)$

$\mathrm{X} 4 \quad=$ Biaya Kolom $\left(\mathrm{Rp} / \mathrm{m}^{2}\right)$

$\mathrm{X} 13=$ Biaya Pekerjaan Lantai $\left(\mathrm{Rp} / \mathrm{m}^{2}\right)$

\section{Pengujian Model}

Biaya estimasi model dihitung dengan persamaan regresi yang telah diperoleh dan dengan memasukkan data biaya yang sudah melalui penyederhanaan data (Tabel 6 dan Tabel 7). Hasil perhitungan selanjutnya dapat dilihat pada Tabel 18.

Tabel 18 Hasil Perhitungan Biaya Estimasi Model

\begin{tabular}{|r|r|r|r|r|r|r|}
\hline No. & $\begin{array}{c}\text { Pek. Pondasi } \\
(\mathrm{X} 2)\left(\mathrm{Rp} / \mathrm{m}^{2}\right)\end{array}$ & $\begin{array}{c}\text { Pek. Dinding } \\
(\mathrm{X} 10)\left(\mathrm{Rp} / \mathrm{m}^{2}\right)\end{array}$ & $\begin{array}{c}\text { Pek. Pintu } \\
\text { \&Jendela }(\mathrm{X} 11) \\
\left(\mathrm{Rp} / \mathrm{m}^{2}\right)\end{array}$ & $\begin{array}{c}\text { Pek. Kolom } \\
(\mathrm{X} 4)\left(\mathrm{Rp} / \mathrm{m}^{2}\right)\end{array}$ & $\begin{array}{c}\text { Pek. Lantai } \\
(\mathrm{X} 13)\left(\mathrm{Rp} / \mathrm{m}^{2}\right)\end{array}$ & $\begin{array}{c}\text { Biaya Estimasi } \\
\text { Model }(\mathrm{Y}) \\
\left(\mathrm{Rp} / \mathrm{m}^{2}\right)\end{array}$ \\
\hline 1 & $854.242,18$ & $1.035 .864,75$ & $337.621,08$ & $226.117,66$ & $374.316,88$ & $5.627 .744,31$ \\
\hline 2 & $1.197 .496,46$ & $629.439,04$ & $551.924,97$ & $577.720,77$ & $598.252,37$ & $7.851 .059,84$ \\
\hline 3 & $1.326 .653,00$ & $1.546 .782,50$ & $992.398,94$ & $765.764,71$ & $736.058,91$ & $11.432 .348,49$ \\
\hline 4 & $1.586 .035,41$ & $1.546 .782,50$ & $992.398,94$ & $765.764,71$ & $736.058,91$ & $12.256 .014,88$ \\
\hline 5 & $348.150,67$ & $417.898,04$ & $456.216,05$ & $418.586,17$ & $197.424,01$ & $5.768 .539,27$ \\
\hline 6 & $334.150,50$ & $374.445,81$ & $265.562,99$ & $408.841,58$ & $258.293,73$ & $4.093 .592,34$ \\
\hline 7 & $553.301,01$ & $520.053,40$ & $311.965,71$ & $130.462,49$ & $367.567,18$ & $4.186 .295,31$ \\
\hline 8 & $158.434,89$ & $380.793,15$ & $343.387,56$ & $275.304,16$ & $364.933,55$ & $3.396 .819,81$ \\
\hline 9 & $133.034,36$ & $569.144,30$ & $536.099,48$ & $377.547,88$ & $491.673,39$ & $4.404 .195,25$ \\
\hline
\end{tabular}

Sumber: Pengolahan Data Ms. Excel 
Selanjutnya mencari Cost Model Factor (CMF), hasilnya terdapat pada Tabel 19.

Tabel 19 Hasil Perhitungan Cost Model Factor

\begin{tabular}{|r|c|r|c|c|}
\hline No. & Tahun & $\begin{array}{c}\text { Biaya Estimasi } \\
\text { Model }\left(\mathrm{Rp} / \mathrm{m}^{2}\right)\end{array}$ & $\begin{array}{c}\text { Biaya Estimasi } \\
\text { Aktual }\left(\mathrm{Rp} / \mathrm{m}^{2}\right)\end{array}$ & $\begin{array}{c}\text { Cost Model } \\
\text { Factor }(\mathrm{CMF})\end{array}$ \\
\hline & & $\mathrm{a}$ & $\mathrm{b}$ & $\mathrm{c}=\mathrm{a} / \mathrm{b}$ \\
\hline 1 & 2013 & $5.627 .744,31$ & $5.368 .504,42$ & 1,05 \\
\hline 2 & 2013 & $7.851 .059,84$ & $7.568 .750,39$ & 1,04 \\
\hline 3 & 2014 & $11.432 .348,49$ & $11.230 .133,71$ & 1,02 \\
\hline 4 & 2014 & $12.256 .014,88$ & $11.535 .130,75$ & 1,06 \\
\hline 5 & 2014 & $5.768 .539,27$ & $5.617 .978,04$ & 1,03 \\
\hline 6 & 2014 & $4.093 .592,34$ & $3.408 .189,71$ & 1,20 \\
\hline 7 & 2015 & $4.186 .295,31$ & $3.785 .213,63$ & 1,11 \\
\hline 8 & 2015 & $3.396 .819,81$ & $3.636 .365,97$ & 0,93 \\
\hline 9 & 2016 & $4.404 .195,25$ & $4.258 .636,38$ & 1,03 \\
\hline \multicolumn{5}{|c|}{ Rata-Rata CMF } \\
\hline
\end{tabular}

Sumber: Pengolahan Data Ms. Excel

Dilanjutkan dengan menghitung biaya estimasi Cost Significant Model (CSM), hasil perhitungan dapat dilihat pada Tabel 20.

Tabel 20 Hasil Biaya Estimasi Cost Significant Model

\begin{tabular}{|r|c|r|r|r|c|c|}
\hline No. & Tahun & $\begin{array}{c}\text { Luas } \\
\text { Proyek } \\
\left(\mathrm{m}^{2}\right)\end{array}$ & $\begin{array}{c}\text { Biaya Estimasi } \\
\text { Model }\left(\mathrm{Rp} / \mathrm{m}^{2}\right)\end{array}$ & $\begin{array}{c}\text { Biaya Estimasi } \\
\text { Model (Rp) }\end{array}$ & CMF & $\begin{array}{c}\text { Biaya Estimasi Cost } \\
\text { Significant Model } \\
(\mathrm{Rp})\end{array}$ \\
\hline & & $\mathrm{a}$ & $\mathrm{b}$ & $\mathrm{c}=\mathrm{a}$ x b & $\mathrm{d}$ & $\mathrm{e}=\mathrm{c} / \mathrm{d}$ \\
\hline 1 & 2013 & 388,58 & $5.627 .744,31$ & $2.186 .828 .885,22$ & & $2.078 .677 .896,84$ \\
\hline 2 & 2013 & 960,00 & $7.851 .059,84$ & $7.537 .017 .450,78$ & & $7.164 .269 .545,22$ \\
\hline 3 & 2014 & 405,00 & $11.432 .348,49$ & $4.630 .101 .139,70$ & & $4.401 .116 .595,92$ \\
\hline 4 & 2014 & 405,00 & $12.256 .014,88$ & $4.963 .686 .025,89$ & \multirow{3}{*}{1,05} & $4.718 .203 .833,22$ \\
\hline 5 & 2014 & 1014,6 & $5.768 .539,27$ & $5.852 .759 .939,09$ & $5.563 .308 .040,73$ \\
\hline 6 & 2014 & 1084,85 & $4.093 .592,34$ & $4.440 .933 .650,34$ & & $4.221 .304 .502,90$ \\
\hline 7 & 2015 & 493,22 & $4.186 .295,31$ & $2.064 .764 .573,07$ & & $1.962 .650 .351,48$ \\
\hline 8 & 2015 & 1500,00 & $3.396 .819,81$ & $5.095 .229 .707,85$ & & $4.843 .241 .940,22$ \\
\hline 9 & 2016 & 515,53 & $4.404 .195,25$ & $2.270 .494 .778,55$ & & $2.158 .206 .041,15$ \\
\hline
\end{tabular}

Sumber: Pengolahan Data Ms. Excel

Dilanjutkan dengan menghitung Akurasi Cost Significant Model, hasil analisa dapat dilihat pada Tabel 21.

Tabel 21 Hasil Akurasi Biaya Estimasi Cost Significant Model

\begin{tabular}{|r|c|c|c|c|c|}
\hline No. & Tahun & $\begin{array}{c}\text { Biaya Aktual Proyek } \\
(\mathrm{Rp})\end{array}$ & $\begin{array}{c}\text { Biaya Estimasi Cost } \\
\text { Significant Model } \\
(\mathrm{Rp})\end{array}$ & $\begin{array}{c}\text { Akurasi Biaya } \\
\text { Estimasi Cost } \\
\text { Significant Model (\%) })\end{array}$ & $\begin{array}{c}\text { Akurasi Biaya } \\
\text { Estimasi Cost } \\
\text { Significant Model }\end{array}$ \\
\hline & & $\mathrm{a}$ & $\mathrm{b}$ & $\mathrm{c}=((\mathrm{b}-\mathrm{a}) / \mathrm{a}) \times 100 \%$ & $\mathrm{~d}=\mathrm{c} \times \mathrm{a}$ \\
\hline 1 & 2013 & $2.086 .093 .446,30$ & $2.078 .677 .896,84$ & $0 \%$ & $-7.415 .549,46$ \\
\hline 2 & 2013 & $7.266 .000 .375,55$ & $7.164 .269 .545,22$ & $-1 \%$ & $-101.730 .830,33$ \\
\hline 3 & 2014 & $4.548 .204 .154,40$ & $4.401 .116 .595,92$ & $-3 \%$ & $-147.087 .558,48$ \\
\hline 4 & 2014 & $4.671 .727 .952,46$ & $4.718 .203 .833,22$ & $1 \%$ & $46.475 .880,76$ \\
\hline 5 & 2014 & $5.700 .000 .515,07$ & $5.563 .308 .040,73$ & $-2 \%$ & $-136.692 .474,33$ \\
\hline 6 & 2014 & $3.697 .374 .603,80$ & $4.221 .304 .502,90$ & $14 \%$ & $523.929 .899,10$ \\
\hline 7 & 2015 & $1.866 .943 .065,59$ & $1.962 .650 .351,48$ & $5 \%$ & $95.707 .285,89$ \\
\hline 8 & 2015 & $5.454 .548 .961,67$ & $4.843 .241 .940,22$ & $-11 \%$ & $-611.307 .021,45$ \\
\hline 9 & 2016 & $2.195 .454 .811,12$ & $2.158 .206 .041,15$ & $-2 \%$ & $-37.248 .769,97$ \\
\hline
\end{tabular}

Sumber: Pengolahan Data Ms. Excel

\section{Analisa dengan Metode Parametrik}

Berikut adalah langkah-langkah analisa dengan metode parametrik:

\section{Mengumpulkan Data dan Menentukan Parameter}

Parameter yang digunakan data dapat dilihat pada Tabel 22.

\section{Mengklasifikasikan Bangunan}

Klasifikasi bangunan 2 (dua) lantai yang penulis teliti digolongkan menjadi 2 bagian, untuk lebih rincinya dapat dilihat pada Tabel 23. 
Tabel 22 Rekapitulasi Data Proyek Pembangunan Gedung 2 (dua) Lantai di Sumatera Barat Tahun 2013 s.d. 2016

\begin{tabular}{|r|r|r|r|}
\hline No. & Tahun & $\begin{array}{c}\text { Biaya Tiotal Proyek } \\
(\mathrm{Y})(\mathrm{Rp})\end{array}$ & $\begin{array}{r}\text { Luas Proyek } \\
\left(\mathrm{m}^{2}\right)\end{array}$ \\
\hline 1 & 2013 & $2.086 .093 .446,30$ & 388,58 \\
\hline 2 & 2013 & $7.266 .000 .375,55$ & 960,00 \\
\hline 3 & 2014 & $4.548 .204 .154,40$ & 405,00 \\
\hline 4 & 2014 & $4.671 .727 .952,46$ & 405,00 \\
\hline 5 & 2014 & $5.700 .000 .515,07$ & 1014,60 \\
\hline 6 & 2014 & $3.697 .374 .603,80$ & 1084,85 \\
\hline 7 & 2015 & $1.866 .943 .065,59$ & 493,22 \\
\hline 8 & 2015 & $5.454 .548 .961,67$ & 1500,00 \\
\hline 9 & 2016 & $2.195 .454 .811,12$ & 515,53 \\
\hline
\end{tabular}

Sumber: Pengolahan Data Ms. Excel

Tabel 23 Klasifikasi Bangunan

\begin{tabular}{|r|c|r|l|}
\hline No. & Tahun & $\begin{array}{c}\text { Luas } \\
\text { Proyek }\end{array}$ & Klasifikasi Bangunan \\
\hline 1 & 2013 & 388,58 & $*$ Luas Proyek $\leq 500 \mathrm{~m}^{2}$, Bangunan Sederhana \\
\hline 2 & 2013 & 960,00 & $*$ Luas Proyek $\geq 500 \mathrm{~m}^{2}$, Bangunan Tidak Sederhana \\
\hline 3 & 2014 & 405,00 & $*$ Luas Proyek $\leq 500 \mathrm{~m}^{2}$, Bangunan Sederhana \\
\hline 4 & 2014 & 405,00 & $*$ Luas Proyek $\leq 500 \mathrm{~m}^{2}$, Bangunan Sederhana \\
\hline 5 & 2014 & 1014,6 & $*$ Luas Proyek $\geq 500 \mathrm{~m}^{2}$, Bangunan Tidak Sederhana \\
\hline 6 & 2014 & 1084,85 & $*$ Luas Proyek $\geq 500 \mathrm{~m}^{2}$, Bangunan Tidak Sederhana \\
\hline 7 & 2015 & 493,22 & $*$ Luas Proyek $\leq 500 \mathrm{~m}^{2}$, Bangunan Sederhana \\
\hline 8 & 2015 & 1500,00 & $*$ Luas Proyek $\geq 500 \mathrm{~m}^{2}$, Bangunan Tidak Sederhana \\
\hline 9 & 2016 & 515,53 & $*$ Luas Proyek $\geq 500 \mathrm{~m}^{2}$, Bangunan Tidak Sederhana \\
\hline
\end{tabular}

Sumber: Pengolahan Data Ms. Excel

\section{Mengumpulkan informasi HSBGN Per $\mathrm{M}^{2}$}

Harga gedung per $\mathrm{m}^{2}$ yang digunakan adalah harga yang dikeluarkan oleh Direktur Jendral Pajak, karena data harga dari provinsi Sumatera Barat tidak ditemukan. Harga yang diperoleh dari Dirjen Pajak hanya mencakup tahun 2013 dan 2014, yang dapat dilihat pada Tabel 24 dan Tabel 25.

Tabel 24 Harga Gedung Per M $^{2}$ Tahun 2013

\begin{tabular}{|c|c|c|c|c|c|c|}
\hline \multicolumn{2}{|c|}{ HARGA GEDUNG PER M ${ }^{2}\left(\mathrm{Rp} / \mathrm{m}^{2}\right)$} \\
\hline \multicolumn{2}{|c|}{ GEDUNG BERTINGKAT } & \multicolumn{2}{|c|}{ GEDUNG TIDAK BERTINGKAT } & \multicolumn{3}{c|}{ RUMAH NEGARA } \\
\hline $\begin{array}{c}\text { BANGUNAN } \\
\text { SEDERHANA }\end{array}$ & $\begin{array}{c}\text { BANGUNAN } \\
\text { TIDAK } \\
\text { SEDERHANA }\end{array}$ & $\begin{array}{c}\text { BANGUNAN } \\
\text { SEDERHANA }\end{array}$ & $\begin{array}{c}\text { BANGUNAN } \\
\text { TIDAK } \\
\text { SEDERHANA }\end{array}$ & TIPE A & TIPE B & TIPEC \\
\hline 1 & 2 & 3 & 4 & 5 & 6 & 7 \\
\hline $4.553 .000,00$ & $6.374 .000,00$ & $3.339 .000,00$ & $4.676 .000,00$ & $3.805 .000,00$ & $3.805 .000,00$ & $3.004 .000,00$ \\
\hline
\end{tabular}


Tabel 25 Harga Gedung Per $\mathrm{M}^{2}$ Tahun 2014

\begin{tabular}{|c|c|c|c|c|c|c|}
\hline \multicolumn{7}{|c|}{ HARGA GEDUNG PER M ${ }^{2}\left(\mathrm{Rp} / \mathrm{m}^{2}\right)$} \\
\hline \multicolumn{2}{|c|}{ GEDUNG BERTINGKAT } & \multicolumn{2}{|c|}{ GEDUNG TIDAK BERTINGKAT } & \multicolumn{3}{c|}{ RUMAH NEGARA } \\
\hline $\begin{array}{c}\text { BANGUNAN } \\
\text { SEDERHANA }\end{array}$ & $\begin{array}{c}\text { BANGUNAN } \\
\text { TIDAK } \\
\text { SEDERHANA }\end{array}$ & $\begin{array}{c}\text { BANGUNAN } \\
\text { SEDERHANA }\end{array}$ & $\begin{array}{c}\text { BANGUNAN } \\
\text { TIDAK } \\
\text { SEDERHANA }\end{array}$ & TIPE A & TIPE B & TIPE C \\
\hline 1 & 2 & 3 & 4 & 5 & 6 & 7 \\
\hline $4.780 .650,00$ & $6.692 .700,00$ & $3.505 .950,00$ & $4.909 .800,00$ & $3.995 .250,00$ & $3.995 .250,00$ & $3.154 .200,00$ \\
\hline
\end{tabular}

Untuk menutupi kekurangan data, maka penulis memproyeksikan Harga Gedung Per $\mathrm{M}^{2}$ Tahun 2014 ke tahun 2015 s.d. 2016 menggunakan angka inflasi umum tahunan negara Republik Indonesia tahun 2014, yang terdapat pada Tabel 26.

Tabel 26 Inflasi Tahunan Republik Indonesia

\begin{tabular}{|r|c|c|c|}
\hline No & Tahun & $\begin{array}{c}\text { Inflasi } \\
(\%)\end{array}$ & Inflasi \\
\hline 1 & 2014 & 8,36 & 0,0836 \\
\hline
\end{tabular}

Sumber: Badan Pusat Statistik

Hasil proyeksi dapat dilihat pada Tabel 27 s.d. Tabel 28.

Tabel 27 Harga Gedung Per M² Tahun 2015 Hasil dari Proyeksi Tahun 2014

\begin{tabular}{|c|c|c|c|c|c|c|}
\hline \multicolumn{7}{|c|}{ HARGA GEDUNG PER M ${ }^{2}\left(\mathrm{Rp} / \mathrm{m}^{2}\right)$} \\
\hline \multicolumn{2}{|c|}{ GEDUNG BERTINGKAT } & GEDUNG TIDAK BERTINGKAT & \multicolumn{3}{c|}{ RUMAH NEGARA } \\
\hline $\begin{array}{c}\text { BANGUNAN } \\
\text { SEDERHANA }\end{array}$ & $\begin{array}{c}\text { BANGUNAN } \\
\text { TIDAK } \\
\text { SEDERHANA }\end{array}$ & $\begin{array}{c}\text { BANGUNAN } \\
\text { SEDERHANA }\end{array}$ & $\begin{array}{c}\text { BANGUNAN } \\
\text { TIDAK } \\
\text { SEDERHANA }\end{array}$ & TIPE A & TIPE B & TIPEC \\
\hline 1 & 2 & 3 & 4 & 5 & 6 & 7 \\
\hline 5.180.312,34 & $7.252 .209,72$ & $3.799 .047,42$ & $5.320 .259,28$ & $4.329 .252,90$ & $4.329 .252,90$ & $3.417 .891,12$ \\
\hline
\end{tabular}

Tabel 28 Harga Gedung Per M $^{2}$ Tahun 2016 Hasil dari Proyeksi Tahun 2014

\begin{tabular}{|c|c|c|c|c|c|c|}
\hline \multicolumn{7}{|c|}{ HARGA GEDUNG PER M ${ }^{2}\left(\mathrm{Rp} / \mathrm{m}^{2}\right)$} \\
\hline \multicolumn{2}{|c|}{ GEDUNG BERTINGKAT } & \multicolumn{2}{|c|}{ GEDUNG TIDAK BERTINGKAT } & \multicolumn{3}{c|}{ RUMAH NEGARA } \\
\hline $\begin{array}{c}\text { BANGUNAN } \\
\text { SEDERHANA }\end{array}$ & $\begin{array}{c}\text { BANGUNAN } \\
\text { TIDAK } \\
\text { SEDERHANA }\end{array}$ & $\begin{array}{c}\text { BANGUNAN } \\
\text { SEDERHANA }\end{array}$ & $\begin{array}{c}\text { BANGUNAN } \\
\text { TIDAK } \\
\text { SEDERHANA }\end{array}$ & TIPE A & TIPE B & TIPEC \\
\hline 1 & 2 & 3 & 4 & 5 & 6 & 7 \\
\hline 5.613.386,45 & $7.858 .494,45$ & $4.116 .647,78$ & $5.765 .032,96$ & $4.691 .178,44$ & $4.691 .178,44$ & $3.703 .626,82$ \\
\hline
\end{tabular}


Data harga gedung yang akan digunakan telah dirangkum pada Tabel 29.

Tabel 29 Harga Gedung Per $\mathrm{M}^{2}$ untuk Gedung Bertingkat Tahun 2013 s.d. 2016

\begin{tabular}{|c|c|c|c|c|c|}
\hline \multirow{3}{*}{ No } & \multirow{3}{*}{ TAHUN } & \multicolumn{4}{|c|}{ HARGA GEDUNG PER M ${ }^{2}$} \\
\hline & & \multicolumn{4}{|c|}{ GEDUNG BERTINGKAT } \\
\hline & & \multicolumn{2}{|c|}{$\begin{array}{l}\text { BANGUNAN } \\
\text { SEDERHANA }\end{array}$} & & $\begin{array}{l}\text { NGUNAN } \\
\text { TIDAK } \\
\text { DERHANA }\end{array}$ \\
\hline 1 & 2013 & & $4.553 .000,00$ & $\mathrm{Rp}$ & $6.374 .000,00$ \\
\hline 2 & 2014 & $\mathrm{Rp}$ & $4.780 .650,00$ & $\mathrm{Rp}$ & $6.692 .700,00$ \\
\hline 3 & 2015 & $\mathrm{Rp}$ & $5.180 .312,34$ & $\mathrm{Rp}$ & $7.252 .209,72$ \\
\hline 4 & 2016 & $\mathrm{Rp}$ & $5.613 .386,45$ & $\mathrm{Rp}$ & $7.858 .494,45$ \\
\hline
\end{tabular}

Sumber: Pengolahan Data Ms. Excel

Mencari Koefesien/Faktor Pengali Sesuai Dengan Jenis Proyek

Koefesien yang digunakan dapat dilihat pada Tabel 30.

Tabel 30 Koefesien/Faktor Pengali Jumlah Lantai Bangunan

\begin{tabular}{|l|c|}
\hline \hline Jumlah Lantai Bangunan & Koefisien / Faktor Pengali \\
\hline \hline Bangunan 2 Lantai & 1,090 \\
\hline \hline
\end{tabular}

Sumber: PERPRES No. 73 Tahun 2011 Pasal 10

Melakukan Estimasi Proyek dengan Metode Parametrik

Dengan rumusan yang telah ditetapkan dalam Peraturan Presiden No. 73 Tahun 2011 Pasal 14. Biaya Estimasi Proyek dapat dilihat pada Tabel 31.

Tabel 31 Biaya Estimasi Proyek dengan Metode Parametrik

\begin{tabular}{|c|c|c|c|c|c|}
\hline No. & Tahun & $\begin{array}{l}\text { Harga Gedung } \\
\qquad\left(\mathrm{Rp} / \mathrm{m}^{2}\right)\end{array}$ & $\begin{array}{l}\text { Koefesien Gedung } \\
2 \text { Lantai }\end{array}$ & $\begin{array}{l}\text { Luas Proyek } \\
\qquad\left(\mathrm{m}^{2}\right)\end{array}$ & $\begin{array}{c}\text { Biaya Estimasi Parametrik } \\
\text { (Rp) }\end{array}$ \\
\hline & & $\mathrm{a}$ & $\mathrm{b}$ & $\mathrm{c}$ & $\mathrm{d}=\mathrm{a} \times \mathrm{b} \times \mathrm{c}$ \\
\hline 1 & 2013 & $4.553 .000,00$ & \multirow{9}{*}{1,09} & 388,58 & $1.928 .433 .166,60$ \\
\hline 2 & 2013 & $6.374 .000,00$ & & 960,00 & $6.669 .753 .600,00$ \\
\hline 3 & 2014 & $4.780 .650,00$ & & 405,00 & $2.110 .417 .942,50$ \\
\hline 4 & 2014 & $4.780 .650,00$ & & 405,00 & $2.110 .417 .942,50$ \\
\hline 5 & 2014 & $6.692 .700,00$ & & 1014,6 & $7.401 .550 .627,80$ \\
\hline 6 & 2014 & $6.692 .700,00$ & & 1084,85 & 7.914.027.398,55 \\
\hline 7 & 2015 & $5.180 .312,34$ & & 493,22 & $2.784 .986 .681,04$ \\
\hline 8 & 2015 & $7.252 .209,72$ & & 1500,00 & $11.857 .362 .892,20$ \\
\hline 9 & 2016 & $7.858 .494,45$ & & 515,53 & $4.415 .905 .713,21$ \\
\hline
\end{tabular}

Sumber: Pengolahan Data Ms. Excel

\section{Akurasi Metode Parametrik}

Hasil perhitunga Akurasi Metode Parametrik, dapat dilihat pada Tabel 32. 
Tabel 32 Akurasi Biaya Estimasi dengan Metode Parametrik

\begin{tabular}{|r|c|c|c|c|r|}
\hline No. & Tahun & $\begin{array}{c}\text { Biaya Aktual Proyek } \\
(\mathrm{Rp})\end{array}$ & $\begin{array}{c}\text { Biaya Estimasi } \\
\text { Parametrik (Rp) }\end{array}$ & $\begin{array}{c}\text { Akurasi Metode } \\
\text { Parametrik (\%) }\end{array}$ & $\begin{array}{c}\text { Akurasi Metode } \\
\text { Parametrik (Rp) }\end{array}$ \\
\hline & & $\mathrm{a}$ & $\mathrm{b}$ & $\mathrm{c}=((\mathrm{b}-\mathrm{a}) / \mathrm{a}) \times \mathrm{x} 100 \%$ & $\mathrm{~d}=\mathrm{c} \times \mathrm{a}$ \\
\hline 1 & 2013 & $2.086 .093 .446,30$ & $1.928 .433 .166,60$ & $-8 \%$ & $-157.660 .279,70$ \\
\hline 2 & 2013 & $7.266 .000 .375,55$ & $6.669 .753 .600,00$ & $-8 \%$ & $-596.246 .775,55$ \\
\hline 3 & 2014 & $4.548 .204 .154,40$ & $2.110 .417 .942,50$ & $-54 \%$ & $-2.437 .786 .211,90$ \\
\hline 4 & 2014 & $4.671 .727 .952,46$ & $2.110 .417 .942,50$ & $-55 \%$ & $-2.561 .310 .009,96$ \\
\hline 5 & 2014 & $5.700 .000 .515,07$ & $7.401 .550 .627,80$ & $30 \%$ & $1.701 .550 .112,73$ \\
\hline 6 & 2014 & $3.697 .374 .603,80$ & $7.914 .027 .398,55$ & $114 \%$ & $4.216 .652 .794,75$ \\
\hline 7 & 2015 & $1.866 .943 .065,59$ & $2.784 .986 .681,04$ & $49 \%$ & $918.043 .615,45$ \\
\hline 8 & 2015 & $5.454 .548 .961,67$ & $11.857 .362 .892,20$ & $117 \%$ & $6.402 .813 .930,53$ \\
\hline 9 & 2016 & $2.195 .454 .811,12$ & $4.415 .905 .713,21$ & $101 \%$ & $2.220 .450 .902,09$ \\
\hline
\end{tabular}

Sumber: Pengolahan Data Ms. Excel

\section{Perbandingan Akurasi Cost Significant Model dan Metode Parametrik}

Perbandingan akurasi hasil estimasi dari kedua metode dapat dilihat pada Tabel 33.

Tabel 33 Perbandingan Akurasi Model

\begin{tabular}{|c|c|c|c|c|c|}
\hline No. & Tahun & $\begin{array}{c}\text { Akurasi Cost } \\
\text { Significant } \\
\text { Model (\%) }\end{array}$ & $\begin{array}{c}\text { Akurasi } \\
\text { Metode } \\
\text { Parametrik (\%) }\end{array}$ & $\begin{array}{c}\text { Akurasi Cost } \\
\text { Significant Model } \\
(\mathrm{Rp})\end{array}$ & $\begin{array}{c}\text { Akurasi Metode } \\
\text { Parametrik (Rp) }\end{array}$ \\
\hline 1 & 2013 & $0 \%$ & $-8 \%$ & $-157.660 .279,70$ & $-157.660 .279,70$ \\
\hline 2 & 2013 & $-1 \%$ & $-8 \%$ & $-596.246 .775,55$ & $-596.246 .775,55$ \\
\hline 3 & 2014 & $-3 \%$ & $-54 \%$ & $-2.437 .786 .211,90$ & $-2.437 .786 .211,90$ \\
\hline 4 & 2014 & $1 \%$ & $-55 \%$ & $-2.561 .310 .009,96$ & $-2.561 .310 .009,96$ \\
\hline 5 & 2014 & $-2 \%$ & $30 \%$ & $1.701 .550 .112,73$ & $1.701 .550 .112,73$ \\
\hline 6 & 2014 & $14 \%$ & $114 \%$ & $4.216 .652 .794,75$ & $4.216 .652 .794,75$ \\
\hline 7 & 2015 & $5 \%$ & $49 \%$ & $918.043 .615,45$ & $918.043 .615,45$ \\
\hline 8 & 2015 & $-11 \%$ & $117 \%$ & $6.402 .813 .930,53$ & $6.402 .813 .930,53$ \\
\hline 9 & 2016 & $-2 \%$ & $101 \%$ & $2.220 .450 .902,09$ & $2.016 .282 .503,94$ \\
\hline \multicolumn{2}{|c|}{ Nilai \% Max } & $14 \%$ & $117 \%$ & $6.402 .813 .930,53$ & $6.402 .813 .930,53$ \\
\hline \multicolumn{2}{|c|}{ Nilai \% Min } & $-11 \%$ & $-55 \%$ & $-2.561 .310 .009,96$ & $-2.561 .310 .009,96$ \\
\hline$\%$ Rata-Rata & $0 \%$ & $32 \%$ & $1.078 .500 .897,60$ & $1.055 .815 .520,03$ \\
\hline
\end{tabular}

Sumber: Pengolahan Data Ms. Excel

\section{SIMPULAN}

Berdasarkan penelitian yang telah dilakukan, maka penulis menyimpulkan sebagai berikut:

1. Komponen yang berpengaruh dalam perhitungan estimasi biaya adalah sebagai berikut:

- Komponen yang berpengaruh dalam hasil estimasi Cost Significant Model, yaitu: komponen biaya Pekerjaan Pondasi, Pekerjaan Dinding, Pekerjaan Pintu dan Jendela, Pekerjaan Kolom, dan Pekerjaan Lantai.
- Komponen yang berpengaruh dalam hasil estimasi Metode Parametrik, hanya Harga Satuan Bangunan Gedung Negara (HSBGN).

2. Pada penelitian ini, Cost Significant Model memiliki hasil yang akurat namun sulit diterapkan pada proyek pemerintah yang membutuhkan pertanggungjawaban karena metode ini tidak memiliki standar yang pasti serta masih dalam penelitian. Metode Parametrik walaupun memiliki hasil kurang akurat tetapi hasil perhitungannya dapat dipertanggungjawabkan karena 
menggunakan standar yang ditetapkan oleh pemerintah.

3. Perbandingan akurasi terhadap kedua metode adalah sebagai berikut:

- Akurasi Cost Significant Model, berkisar antara $-11 \%$ s.d. $14 \%$ dengan rata-rata $0 \%$.

- Kekurangan Biaya Total Proyek terbesar hasil estimasi biaya dengan CSM terjadi pada data ke 8 (delapan), proyek tahun 2015 sebesar Rp. -611.307.021,45.

- Kelebihan Biaya Total Proyek terbesar pada hasil estimasi biaya dengan CSM terjadi pada data ke 6 (enam), proyek tahun 2014 sebesar Rp. 523.929.899,10.

- Akurasi Metode Parametrik, berkisar antara $-55 \%$ s.d. $117 \%$ dengan rata-rata $32 \%$.

- Kekurangan Biaya Total Proyek terbesar pada hasil estimasi biaya dengan Metode Parametrik terjadi pada data ke 4 (empat), proyek tahun 2014 sebesar Rp. 2.561.310.009,96.

- Kelebihan Biaya Total Proyek terbesar pada hasil estimasi biaya dengan Metode Parametrik terjadi pada data ke 8 (delapan), proyek tahun 2015 sebesar Rp. 6.402.813.930,53.

Berdasarkan informasi ini diketahui bahwa biaya estimasi dengan Cost Significant Model, lebih akurat dibandingkan biaya estimasi dengan Metode Parametrik, serta akurasi Cost Significant Model juga memenuhi persyaratan akurasi estimasi untuk tahap konseptual menurut AACE Internasional (2005), sehingga disarankan untuk menggunakan Cost Significant Model dalam melakukan estimasi biaya, khusunya pada gedung berlantai 2 (dua).

\section{DAFTAR PUSTAKA}

Akhsa, E. dkk. 2015. Model Estimasi Biaya Pekerjaan Rehabilitasi dan Peningkatan Jaringan Irigasi
Menggunakan Cost Significant Model Studi Kasus Dinas Pengairan Kabupaten Aceh Tenggara (Jurnal). Banda Aceh: Universitas Syiah Kuala.

Ervianto, WI. 2005. Manajemen Proyek Konstruksi (Edisi Revisi), Ed. III. Yogyakarta: ANDI.

Falahis, VD. dkk. 2015. Cost Significant Model Sebagai Dasar Pemodelan Estimasi Biaya Konstruksi Jembatan Beton Bertulang (Jurnal). Surakarta: Universitas Sebelas Maret.

Fikri, RM. dkk. 2015. Analisis Estimasi Biaya Proyek Peningkatan Jalan Beton di Kabupaten Tangerang dengan Cost Significant Model (Seminar Nasional). Jakarta: Universitas Trisakti.

Indrawan, GS. 2011. Estimasi Biaya Pemeliharaan Jalan Dengan Cost Significant Model Studi Kasus di Kabupaten Jembrana Bali. Bali: Universitas Udayana.

Kaming, PF. dkk. 2009. Pengembangan Cost Significant Modelling untuk Estimasi Biaya Proyek Pengairan (Konferensi Nasional). Yogyakarta: Universitas Atma Jaya.

Pemayun. dkk. 2003. Praktek Estimasi Biaya dengan Metode Cost Significant Model pada Bangunan Gedung yang Memakai Arsitektural Bali (Tesis). Yogyakarta: Universitas Atma Jaya.

Soeharto, I. 2001. Manajemen Proyek dari Konseptual sampai Operasional Ed. 2, cet. 1. Jakarta: Erlangga.

Sugiyarto. dkk. 2016. Estimasi Biaya Konstruksi Bangunan Gedung Dengan Metode Cost Significant Model Studi Kasus Proyek Lanjutan Pembangunan Gedung (Jurnal). Surakarta: Universitas Sebelas Maret.

Wahyudi, L. 1994. Perencanaan Biaya Bangunan. Jakarta: Gramedia Pustaka Utama. 